\title{
FEATURES OF FORMATION OF MOTIVATION FOR ONLINE LEARNING OF STUDENTS OF PEDAGOGICAL SPECIALTIES
}

\author{
Tetiana Shrol, Nataliia Poliukhovych
}

The concept of "motivation" and modern theories of learning motivation are theoretically substantiated and described: expectancy-value theory, attribution theory, social-cognitive theory, goal orientation theory, self-determination theory. Teaching strategies and pedagogical conditions that motivate students to educational and cognitive activities in the online environment, taking into account the theory of self-determination, are determined. In particular, in order to succeed in mastering something new, a student must feel competent (acquire the appropriate skills to perform practical tasks), related (feel belonging and attachment to groups or individuals), autonomous (feel that he/she controls his/her behavior and is responsible for its goals, capable of self-learning).

The pedagogical conditions for the formation of positive motivation and involvement of students in learning online are substantiated and determined, namely: giving a student the opportunity to be an accomplice in the learning process; structuring educational materials in accordance with learning objectives; promoting student initiative and creativity, ensuring group activities and a multidimensional assessment system.

The key to fulfilling the pedagogical conditions is the teacher's motivation to implement online learning at the level of the course author, mentor and tutor for higher education students. External and internal factors of motivation of teachers for introduction of elements of distance (online) and mixed (alternation of online and offline) training by teachers in the educational process of establishments of higher education are defined.

Experimentally confirmed: positive impact on the motivation of the implemented online learning strategies and pedagogical conditions; revealed a significant direct relationship between the student's ability to self-development and selflearning and his/her motivation for online learning

Keywords: online learning, blended learning, distance learning, motivation, learning motivation theories

(C) The Author(s) 2021

This is an open access article under the Creative Commons CC BY license

How to cite:

Shrol, T., Poliukhovych, N. (2021). Features of formation of motivation for online learning of students of pedagogical specialties. ScienceRise: Pedagogical Education, 4 (43), 4-11. doi: http://doi.org/10.15587/2519-4984.2021.237825

\section{Introduction}

Intensification and optimization of educational activities in higher education institutions (HEIs) based on the introduction of innovative technologies and distance learning in higher education is one of the operational goals of the Strategy for the Development of Higher Education in Ukraine [1]. It provides for the development of innovative technologies in accordance with the world scientific and technical level, digitalization of all processes in the higher education system and the introduction of distance learning as a form of higher education [1]. This poses a task for society to effectively, competently, reasonably, pedagogically balanced introduction of new forms of education, including mixed (online and offline) and distance (online) and preparation of the younger generation to implement the principle of "lifelong learning". In the dynamically changing information society, educational and cognitive activities are leading. However, an important factor that motivates a person to educational activities, self-development and selfimprovement in the information society is motive. It is especially important in online learning, which is an inte- gral part of blended and distance learning. After all, the degree of self-organization and self-education, and accordingly the degree of freedom and responsibility in the transition from traditional to online (electronic, distance) forms of learning is growing.

\section{Literary review}

A review of scientific and pedagogical literature makes it possible to identify works, in which pedagogical principles of professional motivation of future teachers in traditional learning [2-4] mechanisms and methodological and practical aspects of developing students' motivation for distance learning and blended learning are theoretically substantiated and experimentally tested [5-7]. The relationship between the learning environment (student cohesion, teacher support, involvement, research, task orientation, cooperation and fairness), motivation to learn (focus on learning goals, task value and self-efficacy) and selfregulation during independent learning activities are given in [8]. As noted by D. Ariani [8], motivation to learn is a mediator in the relationship between the learning environment and self-regulation during self-education. 
The number of studies on the problems of motivating students to online learning through information networks, personal mobile devices [9], learning management systems (LMS) [10, 11], digital instrumental environments [12], etc. is growing. In particular, the relationship between intrinsic motivation and enjoyment of online English learning during synchronous and asynchronous communication is presented in [13]. The results of the positive effect of digital learning on learning motivation and learning outcomes of students are reflected in the study [14]. In her work, M. Hartnett [15] presented the generalized results of the study of motivation to learn in the Internet environment, taking into account modern theoretical foundations of motivation.

However, as practice, in particular the last two years of study in EIA (2019/2020 academic year and 2020/2021 academic year), has shown, students in the conditions of distance (completely online) or mixed (alternation of online and offline) learning often lose motivation to acquire new knowledge in a particular discipline, which is provided by the work plan for the acquisition of competencies of the relevant educational program. Therefore, it is important to identify those factors and teaching strategies that will allow students, including future teachers (lecturers), to obtain a quality education, regardless of organization form of educational activities.

\section{Research aim and tasks}

The aim of the study is to find out the strategies and pedagogical conditions for the peculiarities of the formation of motivation for online learning of students of pedagogical specialties. ing tasks:

Achieving this goal involves solving the follow-

1) clarification of the basic concepts of the research and investigation of the basic theories of motivation of training;

2) determining the structure of student motivation and needs that determine students' motives for online learning;

3 ) identification of the main strategies for involving students in online learning activities depending on the type of motivation (internal or external);

4) determination of pedagogical conditions for the development of sustainable motivation for online learning in terms of distance and blended learning;

5) experimental verification of the implementation of teaching strategies and pedagogical conditions for the formation of student motivation in the online environment.

\section{Materials and methods}

To achieve this goal, a theoretical analysis of psychological, pedagogical and scientific-methodological sources was conducted in order to clarify the basic concepts of the research, such as "motivation", "motives", "learning motivation"; approaches to teaching depending on the type of motivation were generalized; methods for the formation of internal motivation, as the main component of productive (quality) readiness of future teachers (lecturers) of computer science (computer disciplines) to independent educational and cognitive activities online were systematized.
The determination of motivation for learning activities was performed according to the method of V. Katashev (modified in question 2) [16], and self-assessment and ability to self-study and self-education - according to the method of V. Andreev ("Assessment of ability to selfdevelopment, self-education") [17]. Note that the questionnaire according to the method of V. Katashev consisted of 6 questions and 44 statements. Each statement was rated by a respondent from 1 (sure "no") to 5 (sure "yes") points. The results were evaluated on four scales (four lines in the questionnaire), each of which corresponded to its level of motivation (low: $1,5,9, \ldots 41$; middle: 2,6 , $10, \ldots, 42$; normal: $3,7,11, \ldots, 43$; high: $4,8,12 \ldots 44)$. There are 11 questions in each scale, so the minimum sum of points can be 11 points, the maximum -55 . The scale, on which the maximum number of points will be scored, determined the level of motivation for learning. With the same number of points on several scales, priority was given to a nominally higher level of motivation. The author emphasizes that high levels of motivation (normal, high) are significant from 33 points and more.

Methods of mathematical statistics were used to confirm the results of the experimental study: Pearson's linear correlation coefficient $r_{x y}$ to assess the relationship between self-esteem, students' ability to learn and selfstudy and their motivation, and Student's t-test to assess the significance of the correlation coefficient $r_{x y}$ [18].

\section{Research results}

In the Ukrainian pedagogical encyclopedic dictionary "Motive - (French motif, from Latin moveo move) - the motivating cause of actions and deeds of a person (that pushes to action). The basis of a motive of human activity is human various needs. As a result of awareness and experience of primary (innate) and secondary (material and spiritual) needs, a person has certain incentives to action, through which these needs are met". It goes on to say that "Motivation is a system of motives, or incentives that motivates a person to specific forms of activity or behavior. Motives can be: ideas and notions, feelings, and experiences that express the material or spiritual needs of a human. The same activity can be carried out for different motives" [19].

Need is a state of a living organism, human personality, social group or society as a whole, which expresses a necessity for something, dependence on the objective conditions of life and is the driving force of their activity [19].

The pedagogical significance of needs follows from their role in the development of personality. The desired learning outcome is made possible by such a pedagogical approach that correctly takes into account the needs of a learner. The leading activity of students is educational and cognitive activities or learning.

Learning motivation is a complex system of impetuses that determine the direction of the individual's activity to obtain, transform and preserve new experiences (knowledge, skills, impetuses, ways of action, impressions, preferences). Understanding learning as an independent directed activity of an individual recognizes the approach to learning motivation as a subjective, internally experienced driving forces of a certain type of activity [20]. 
Each student has his or her own relatively stable set (system) of motives, which is formed before admission or while studying at a HEI. As noted by V. Piddyachy, it depends on his/her worldview, character traits, life and professional experience, intelligence, psychophysical characteristics, etc. [4].

Usually, students of a HEI begin educational and cognitive activities due to the influence of two factors: personal (internal to meet their own needs, understanding, interests, abilities) and situational (external). Accordingly, motivation is divided into internal and external. External motivation is one, caused by objective needs. Internal motivation is a quality of a person who invests personal efforts and continues these efforts for a certain period of time for a specific purpose.

Theories of learning motivation are presented quite thoroughly in the scientific literature [21, 22]:

1) the theory of expectations (values), which considers motivation as a function of expectations of success (the degree of faith of a student that he/she will be successful if tries) and the perceived value of a task (the degree of student perception of personal importance, value or intrinsic interest to the performed task)

2) the theory of attribution, which focuses on causal attributions, created by students to explain activity results, and classifies them in terms of their location (reason internal or external to a student), stability (reason is fixed or may change) and manageability (reason in or outside student's activities).

3) the socio-cognitive theory emphasizes selfefficacy as the main driver of motivated actions, as well as identifies signs that affect future self-efficacy and support self-development and self-education. In particular, the learner's education and activity issues are the result of the interaction between personal, behavioral and environmental factors.

4) the theory of goal orientation (achievement of goals) assumes that students, as a rule, approach responsibly to their own educational and cognitive activities with feelings about mastering the content of a subject (the purpose of acquiring relevant knowledge, skills, competencies), achieving better results than others (the purpose of the approach to efficiency, to get the best grades) or to avoid failures (the purpose of productivity is to avoid a negative result);

5) the theory of self-determination assumes that the optimal effectiveness of educational activities is the result of actions, motivated by internal interests or external values that have become integrated and internalized. Intrinsic motivation forces people to act solely to satisfy their curiosity or desire to learn something new. All other actions are caused by external motivation, which is determined by social values. Externally motivated actions can become self-determined when values are integrated and internalized. That is, motivation varies not only in quantitative terms (size), but also in qualitative (type and orientation). Satisfaction of basic psychosocial needs for independence, competence and kinship contributes to such motivation.
Regardless of theory, motivation can be considered as a process by which purposeful activity is maintained and initiated.

This study, in particular the construction of teaching strategies, is based on the theory of selfdetermination - the theory of internal and external motivation. According to the authors of this theory [22], internal motivation remains an important construct of psychological growth of an individual, reflecting the natural tendency of human to learn and acquire relevant skills, and external - volatile and relatively autonomous and determined by either external control or self-control. According to this theory, both internal and external motivations affect a personality and determine its further development, assimilation of new experience, motivate a person to perform an action. R. Ryan and E. Deci developed a theory of self-determination to explain how to promote internal motivation, as well as how to increase motivation when external pressure acts. Thus, the theory of cognitive assessment (subtheory of self-determination) assumes that the satisfaction of three basic psychosocial needs contributes to internal motivation: autonomy (ability to control own actions), competence (self-efficacy) and kinship (sense of belonging to something or belonging to someone).

Motivation will be understood as a process of forming positive learning motives under the influence of certain psychological and pedagogical conditions that contribute to the personal attitude of future teachers (lecturers) to online learning. In the context of this study, the motivation for online learning is to meet external (social) and internal (personal) needs for mastering information and communication technologies of online learning, willingness to use them in educational and cognitive, further professional activities and for personal development.

Students with internal motivation are interested in a topic, in a discipline, or they already have a certain strategy of personal development, which they are trying to implement. They understand that this is necessary for their future professional activity or to meet their own needs, but they lack knowledge and practice. That is, professional, cognitive and personal motives prevail here, which E. Ilyin [23] refers to the leading factors of educational activity.

Students with external motivation proceed from the fact that they will receive a reward or punishment pragmatic motives (passing a test, exam, getting a diploma of higher education). It is typical for students with low grades. Thus, external motivation arises from the influence of objective incentives that initiate and regulate activities on a student. After all, "arbitrary "compulsory" learning is likely to mean external motivation." [24].

However, the same person may represent different types of listeners - depending on a subject and context of learning. Similarly, motivation is external or internal in different circumstances, and therefore, taking into account researches [15, 24], we believe that teaching strategies will be different (Table 1). 
Teaching strategies for students with different types of motivation

\begin{tabular}{|c|c|}
\hline Motivation type & Teaching strategy \\
\hline Internal & $\begin{array}{l}\text { - To say "thank you" to students for their position and desire to improve their skills and abilities. } \\
\text { This will optimize their inner strength for further training. } \\
\text { - Allocate time for students to work on their personal tasks. If, for example, future information } \\
\text { science teachers or computer science teachers, the tasks should correspond to their future profes- } \\
\text { sional activity or their personal interests, hobbies. Of course, the teacher may have standard exer- } \\
\text { cises and tasks that are mandatory for everyone, but progress will be much more tangible if stu- } \\
\text { dents can work on tasks that are important to them. } \\
\text { - To give a student the opportunity to act in the role of a lecturer (teacher). Students with intrinsic } \\
\text { motivation will usually learn a lot on their own, but they will benefit even more if they share their } \\
\text { knowledge. In the process, other students will also be able to find an activity, so the teacher does } \\
\text { not have to be the only source of information and energy. }\end{array}$ \\
\hline External & $\begin{array}{l}\text { - To identify internal motivational factors. It is necessary to determine, first of all, whether there is } \\
\text { something in the discipline (course, topic) - anything - that can interest students; ask them many } \\
\text { questions about what they can do with the obtained information (knowledge); find connections to } \\
\text { current real-world challenges. } \\
\text { - to find "pain points". If students are unfamiliar with the material, they are unable to imagine in } \\
\text { advance (before the begining) what difficulties it may have to master. But if you identify what irri- } \\
\text { tates students, and show how to deal with this irritation, you can quickly turn external motivation } \\
\text { into internal. } \\
\text { - To avoid spatial explanations and judgments. The theory may seem extremely interesting and } \\
\text { important to the teacher, but students with external motivation will most likely not accept it and } \\
\text { will not delve into it. Therefore, you should choose specific examples and tasks that are directly } \\
\text { related to future professional activities, life situations. } \\
\text { - To use interesting hypothetical examples to arouse internal motivation. For example, start with } \\
\text { the fact that students can be invited to solve an interesting task (web-quest, puzzle, etc.), implement } \\
\text { an individual or group project within the subject, or participate in a competition (internal - within a } \\
\text { group, university, external - regional, international, etc.), then their external motivation will gradu- } \\
\text { ally turn into internal. }\end{array}$ \\
\hline
\end{tabular}

In the process of online learning, which involves self-control of students in choosing the time, place, methods and (or) pace of learning, usually an important role is played by internal motivation. The teacher's task in developing an online course is to ensure the transformation of student's external motivation into internal. Thus, in order for an online course (online learning) to promote active learning activities of students, develop ("feed") intrinsic motivation, it must meet the following needs of a student [16]:

1) Sense of competence. For a student, the indicator of involvement in educational and cognitive activities is a sense of own competence. It is important for the student to know: what knowledge and skills he/she will acquire while studying his/her chosen online course; what he/she can do of what he can't do now; whether he/she will become more capable; whether he/she will be able to solve problems that are too difficult for him/her now; whether he/she will receive tools for future professional activity. It is necessary to show the student what he/she will be able to do in the future and how to learn it (methods, tools, etc.).

2) A sense of autonomy or independence. During online learning, it is important for a student to know that he/she has a choice, and accordingly to feel that not all decisions are made by someone for him/her, everything is personalized. The interests of the student, his/her experience, life, skills and abilities are respected, used and involved, both in designing the content of the discipline, which is implemented in the online course, and in the development of practical tasks.
3) Connectivity or belonging. A student is a participant in the course, teachers and other students invite him/her to work together. However, student cooperation and interaction should take place not only with the teacher or other students, but also with the content.

Note that working with students should be aimed at ensuring that they are able to work with the submitted material, equipment and tools of the digital educational environment for communication and cooperation with each other.

In order to meet the above needs of a student to form the motivation of educational and cognitive activities in the digital educational environment and to promote active in-depth learning, it is necessary to comply with the following pedagogical conditions when developing an online course or planning online learning activities:

- to give a student the opportunity to be an accomplice to learning;

- to structure educational materials according to the purposes of training, having specified which of them are obligatory, and which are optional;

- to promote the initiative and creativity of a student;

- to provide group learning activities (as any digital environment is a social space, so it must take into account social mechanisms - competition, cooperation, mutual learning and mutual evaluation);

- to provide constant and individual feedback on all actions in the course of educational activity, to act as a moderator at interaction of a student with other students; 
- to make the assessment system multidimensional, integrating results from external sources (educational platforms, mobile applications, learning management systems, etc.) into the personal profile and portfolio of a student, which he/she can maintain and develop throughout life, because a higher educational institution is not the only source of knowledge and skills.

To ensure the above pedagogical conditions to increase students' motivation to study in the conditions of alternation of offline and online learning (blended learning), or completely online (distance), the motivation of the teacher to implement online learning at the level of course author, mentor, and tutor plays an important role for applicants for higher education. [25] presents some practical solutions for heads of educational institutions, developers of educational programs and teachers to create a holistic environment for HEI, taking into account both external and internal motivating factors for the introduction of elements of distance (online) learning by teachers. Therefore, taking into account research $[16,25]$, the external factors that positively affect the motivation of teachers to use online learning technologies in the educational process of HEI include:

- formed ICT competence of the teacher for designing and developing various types of electronic educational resources, scenarios of online classes in synchronous (videoconferencing) and asynchronous (collaboration with documents in the cloud, via e-mail, means of implementing various activities of corresponding LMS platforms, etc.) modes;

- readiness of HEIs at the institutional level to develop, implement and adhere to the developed concepts and strategies of distance (completely online) and blended (online and offline) learning, communication systems between students, teachers and administrators;

- constant interaction of the teacher with students to get feedback on the e-learning course (course content, developed educational content, practical tasks, availability of tools, etc.) to further improve the course, and ac- cordingly motivation for online learning and learning outcomes.

The internal factors that positively affect the motivation of teachers to use technologies in teaching are:

- personal attitude and beliefs of teachers about the effective impact of distance and blended learning technologies in the educational process of HEIs;

- availability of professional development programs, online resources for teaching lecturers modern ICT and distance and blended learning technologies for the development of high-quality electronic online courses in relevant disciplines;

- personal "feeding" - job satisfaction.

An attempt to implement all the above materials was realized during the development of e-training courses for studying disciplines "Selected issues of subjectoriented technologies" and "Modern programming technologies" for students of specialty 014.09 Secondary Education (Computer Science) and 015.10 Vocational Education (Computer Technology) of the Rivne State University for the Humanities. For the purity of the pedagogical experiment, the control group (CG) was students of 2019/2020 academic year, 23 people, and the experimental one included students of 2020/2021 academic year, 28 people. For students of the control group, the e-learning course in the Moodle system was built by analogy with lectures and laboratory classes in university classrooms: lecture activities included online lectures in video conferencing format (BigBlueButtonBN, Google Meet, Zoom, etc.) and placement of electronic lectures on the platform in pdf format; laboratory classes and independent work involved the implementation of practical tasks with the loading of results into the Moodle system.

For students of the experimental group, the e-learning course was improved and organized taking into account the data teaching strategies and pedagogical conditions, defined above in table 1 . As a result, the level of motivation and, consequently, the ability to self-study was reflected in stable indicators and at some levels by positive growth (Table 2).

Table 2

The dynamics of motivation levels for online learning of EG and CG students before and after the pedagogical experiment

\begin{tabular}{|c|c|c|c|c|c|c|c|c|c|c|}
\hline \multirow{3}{*}{ Motivation levels } & \multicolumn{4}{|c|}{$\mathrm{CG}$} & \multirow{3}{*}{$\begin{array}{c}\text { Dynamics } \\
\%\end{array}$} & \multicolumn{4}{|c|}{ EG } & \multirow{3}{*}{$\begin{array}{c}\text { Dynamics } \\
\%\end{array}$} \\
\hline & \multicolumn{2}{|c|}{ Before } & \multicolumn{2}{|c|}{ After } & & \multicolumn{2}{|c|}{ Before } & \multicolumn{2}{|c|}{ After } & \\
\hline & persons & $\%$ & persons & $\%$ & & persons & $\%$ & persons & $\%$ & \\
\hline High & 12 & 52.2 & 10 & 43.5 & -8.7 & 10 & 35.7 & 16 & 57.1 & 21.4 \\
\hline normal & 6 & 26.1 & 5 & 21.8 & -4.3 & 9 & 32.1 & 8 & 28.6 & -3.5 \\
\hline middle & 5 & 21.7 & 7 & 30.4 & 8.7 & 8 & 28.6 & 4 & 14.3 & -14.3 \\
\hline Low & 0 & 0.0 & 1 & 4.3 & 4.3 & 1 & 3.6 & 0 & 0.0 & -3.6 \\
\hline Totally & 23 & 100.0 & 23 & 100.0 & & 28 & 100.0 & 28 & 100.0 & \\
\hline
\end{tabular}

Note that V. Katashev in the interpretation of the method uses the three of the four levels - high (4), normal (3), middle (2). Since he believes that a low (1) level is not typical for students. However, as research has shown, when transitioning to senior courses there is a small percentage of students with a low level of motivation - these are the students who are either difficult to study in specialized subjects or they realized that they are studying in the wrong specialty, they have completely different professional interests and preferences. Therefore, it was decided to leave all four levels for the analysis of the obtained empirical data according to the method of V. Katashev [16].

In the scientific literature it is proved, that high self-esteem and the ability to self-development and selfeducation provides, accordingly, high motivation to carry 
out educational and cognitive activities [26, 27] during distance or blended learning. This dependence (quite significant direct connection) is confirmed by the results of the diagnosis of the level of ability to self-education and self-development (according to the method of V. Andreev) and motivation (according to the method of V. Katashev) to study for students of CG and EG. This is evidenced by the value of the Pearson's linear correlation coefficient $r_{x y} \approx 0.67$ at a fairly high level of significance $\alpha=0.01$ (critical value of the Student's t-test $t_{r}>t_{0.01}$ $(6.25>2.44))$.

After graduation in the distance (online) format, students of CG and EG took questionnaires. Among the advantages of distance (online) learning, students named: mobility; the possibility to learn at any time, at your own pace and anywhere; self development; saving money and time to come to university; access to materials at any day and time; availability of educational resources; more time to perform tasks in a comfortable environment; better time distribution, more flexible schedule, the opportunity to learn at your own pace and without separation from the main activity (place of work), etc.

Students included to disadvantages of such training: reduced motivation or lack thereof, technical problems (lack of Internet connection, low power of computer equipment or its absence for practical tasks, etc.), lack of "live" communication with all participants in the educational process, insufficient direct contact with the teacher, lack of practical skills, low probability of developing sociability in online learning, the problem of student identification.

The results of the survey (Fig. 1) of CG and EG students after studying at these courses indicate that the transition to full online learning (distance learning) is not an option for higher education institutions. However, a mixed format of online and offline allows, in particular senior students, who are often already employed in the main specialty, not to drop out of the educational process and acquire competencies, defined by the relevant educational program, and get a highquality education.

\section{Do you want elements of distance (online) learning to be implemented in further?}

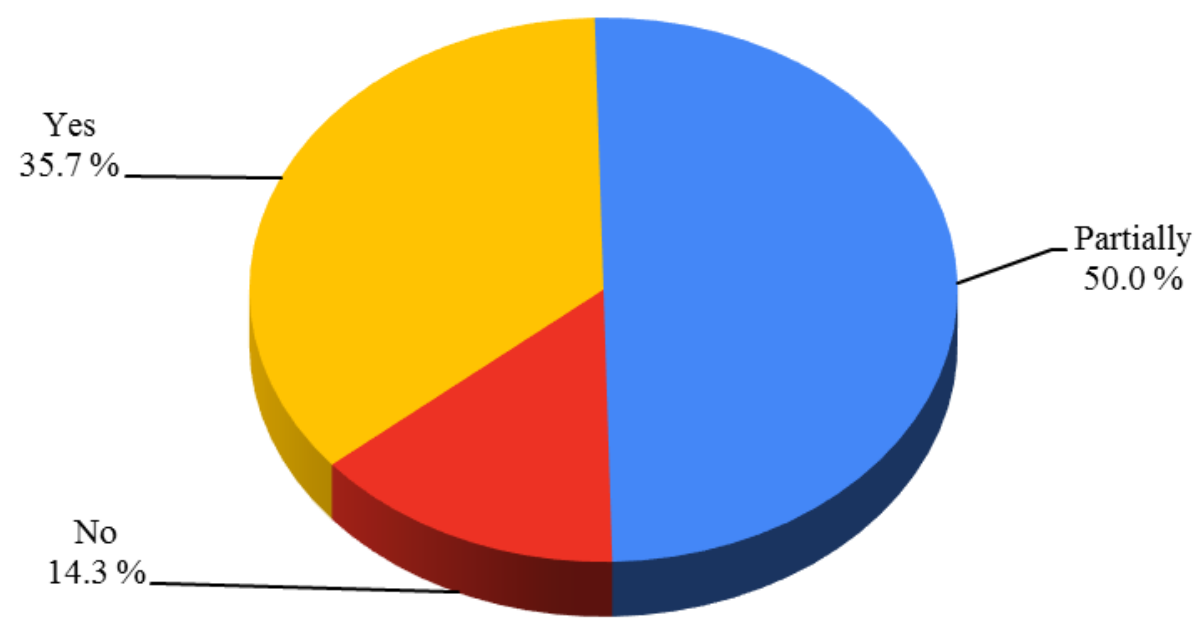

Fig. 1. Students' need in online-learning

\section{Discussion of the research results}

The analysis of the scientific literature on the researched problem of forming students' motivation for online learning made it possible to find out the existence of different approaches to the content, structure, process of forming motivation for online learning in students. This is due to the existence of various theories of learning motivation, including the theory of expectations (values), the theory of attribution, socio-cognitive theory, the theory of goal orientation, the theory of selfdetermination.

However, regardless of theory, learning motivation is defined as a process of forming positive learning motives under the influence of certain psychological and pedagogical conditions that contribute to the personal attitude of future teachers (lecturers) to online learning. In the context of this study, motivation for online learning is to meet external (social) and internal (personal) needs for mastering information and communication technologies of online learning, willingness to use them in educational and cognitive, further professional activities and for personal self-development.

The defined teaching strategies and pedagogical conditions for the formation of student learning motivation, which motivate them to educational and cognitive activities in the online environment, are based on the theory of self-determination (the theory of external and internal motivation). In particular, in order for an online course (online learning) to promote active learning activities of students, develop intrinsic motivation, it must meet such psychosocial needs of a student as: a sense of competence; a sense of autonomy or independence; a sense of connectivity or belonging.

According to the results of the study and the survey of students, among the main problems that arose during distance (online) learning were: reduced motiva- 
tion, lack of communication and interaction with all objects of the educational process and often the inability to implement the set practical course tasks.

To form a positive motivation of students in the development of online courses and planning of online learning activities, one should ensure the implementation of such pedagogical conditions, namely: give a student the opportunity to be a participant in the learning process; to structure educational materials according to the purposes of training; to promote the initiative and creativity of a student, to provide group activities, to make the assessment system multidimensional.

One of the important factors that will ensure the implementation of the described pedagogical conditions is the motivation of a teacher to implement online learning at the level of the course author, mentor, and tutor for higher education applicants. The factors that positively affect the motivation of a teacher to use the technologies of distance and blended learning in the educational process of HEIs are:

- external: ICT competence of a teacher, the readiness of a HEI at the institutional level to develop, implement and adhere to the developed concepts and strategies of distance and blended learning; constant interaction of a teacher and a student to get feedback on the content and organization of online learning;

- internal: personal attitude and beliefs of teachers about the effective impact of distance and blended learning technologies in the educational process of HEIs; availability of professional development programs, online resources for teaching lecturers modern ICT and technologies of distance and blended learning for the development of quality electronic online courses in relevant disciplines; personal "feeding" - job satisfaction.

During the pedagogical experiment, the positive dynamics of the levels of motivation for online learning in EG students as opposed to CG students was revealed. In particular, EG students had a high level increase of $21.4 \%$ and, accordingly, a sufficient level decrease of $3.5 \%$, middle level - by $13.3 \%$, low level - by $3.6 \%$. Whereas CG students decreased at the high and sufficient levels by $8.7 \%$ and $4.3 \%$, respectively, and increased at the middle and low levels by $8.7 \%$ and $4.3 \%$, respectively.

The direct dependence (Pearson's linear correlation coefficient $r_{x y} \approx 0.67$ ) between students' ability to selfstudy and self-education and their motivation to online learning was confirmed at the level of significance $\alpha=0.01$ using Student's t-test $\mathrm{t}_{\mathrm{r}}>\mathrm{t}_{0.01}(6.25>2.44)$.

The practical significance of the study is that its materials can be used by institutions of secondary and higher education for the organization of educational activities, both in distance and blended learning. Taking into account pedagogical strategies and certain pedagogical conditions during the development of e-learning courses, in particular in the Moodle system, to support studying of disciplines and planning of educational activities will provide stable or positive motivation of students to master the course materials and acquire competencies, which formation involves studying of relevant academic disciplines.

Promising areas of further research on this issue include the definition of methodological aspects and pedagogical conditions for the formation of motivation for online teaching of HEI teachers and future teachers in terms of distance and blended learning.

\section{Conclusions}

1. As a result of the research the content of the basic concepts "motivation", "motivation for online learning" is specified and the basic theories of motivation for learning are investigated.

2. The structure of students 'motivation is determined, which is based on the theory of self-determination (theory of external-internal motivation), and the corresponding needs that determine students' motives for online learning. After all, HEI students begin educational and cognitive activities due to the influence of two factors: personal and situational (social). Accordingly, motivation is divided into internal and external.

3. The main strategies for involving students in online learning according to the type of motivation (internal and external) are identified.

4. The pedagogical conditions for the development of sustainable motivation for online learning in terms of distance and blended learning, which should be taken into account when developing an online course and planning online learning activities, are specified.

5 . The positive influence on motivation of the implemented strategies of online learning and pedagogical conditions of formation of students' motivation in the online environment are experimentally confirmed. In addition, the direct relationship was found between the ability to self-study and self-education of students and their motivation for online learning.

\section{References}

1. Stratehii rozvytku vyshchoi osvity v Ukraini na 2021-2031 roky (2020). Kyiv, 71. Available at: https://mon.gov.ua/storage/app/media/rizne/2020/09/25/rozvitku-vishchoi-osviti-v-ukraini-02-10-2020.pdf

2. Voitovych, I. S. (2014). motivzation of future teachers study in their training for professional activity. Naukovi zapysky Ternopilskoho natsionalnoho pedahohichnoho universytetu imeni Volodymyra Hnatiuka. Seriia: Pedahohika, 4, 24-31. Available at: http://nbuv.gov.ua/UJRN/NZTNPU_ped_2014_4_6

3. Nikolaichuk, N. M. (2013). Pedagogical basis formation of future teachers of mathematics professional motivation. Ternopil, 260. Available at: http://dspace.tnpu.edu.ua/handle/123456789/2733

4. Piddiachyi, V. M. (2014). Motivation to Professional Self-Development of Prospective Teachers. Education and Pedagogical Sciences, 2 (163), 41-47. doi: https//doi.org/10.12958/eps.2(163).piddiachyi_v_m

5. Kukharenko, V. M., Bondarenko, V. V. (Eds.) (2020). Ekstrene dystantsiine navchannia v Ukraini. Kharkiv: Vyd-vo KP «Miska drukarnia», 409. Available at: https://duan.edu.ua/images/News/UA/Departments/Management/2020/monograph_ekstr_dyst_navch.pdf

6. Liashenko, I. V. (2015). Development of students motivation to the distance learning in the universities. Osvitolohichnyi dyskurs, 1, 150-157. Available at: http://nbuv.gov.ua/UJRN/osdys_2015_1_16 
7. Voitovych, I. S. (Ed.) (2020). Pidhotovka maibutnikh pedahohiv do vykorystannia informatsiino-komunikatsiinykh tekhnolohii v profesiinii diialnosti. Lutsk, 277.

8. Ariani, D. W. (2017). Relationship Model among Learning Environment, Learning Motivation, and Self-Regulated Learning. Asian Social Science, 13 (9), 63-81. doi: http://doi.org/10.5539/ass.v13n9p63

9. Sari, A. M., Nurcahyo, H. (2018). Improving students learning motivation through mobile learning. Jurnal Pendidikan Biologi Indonesia, 4 (3). doi: http://doi.org/10.22219/jpbi.v4i3.6859

10. Baharudin, A. F., Sahabudin, N. A., Kamaludin, A. (2017). Behavioral Tracking in E-Learning by Using Learning Styles Approach. Indonesian Journal of Electrical Engineering and Computer Science, 8 (1), 17-26. doi: http://doi.org/10.11591/ijeecs.v8.i1.pp17-26

11. Bradley, V. M. (2021). Learning Management System (LMS) Use with Online Instruction. International Journal of Technology in Education, 4 (1), 68-92. doi: http://doi.org/10.46328/ijte.36

12. Harandi, S. R. (2015). Effects of e-learning on Students' Motivation. Procedia - Social and Behavioral Sciences, 181, 423-430. doi: http://doi.org/10.1016/j.sbspro.2015.04.905

13. Bailey, D., Almusharraf, N., Hatcher, R. (2021). Finding satisfaction: intrinsic motivation for synchronous and asynchronous communication in the online language learning context. Education and Information Technologies, 26 (3), 2563-2583. doi: http://doi.org/10.1007/s10639-020-10369-z

14. Lin, M.-H., Chen, H., Kuang-S., L. (2017). A Study of the Effects of Digital Learning on Learning Motivation and Learning Outcome. EURASIA Journal of Mathematics, Science and Technology Education, 13 (7), 3553-3564. doi: http://doi.org/10.12973/ eurasia.2017.00744a

15. Hartnett, M. (2016). The Importance of Motivation in Online Learning. Motivation in Online Education. Singapore: Springer, 5-32. doi: http://doi.org/10.1007/978-981-10-0700-2_2

16. Shrol, T. S. (2017). Formation of ICT Competence of Future Mathematics Teachers. Kyiv, 354. Available at: https://ihed.org.ua/wp-content/uploads/2019/01/Shrol_20-06-2018_disertac.pdf

17. Andreev, V. I. (2012). Pedagogika. Kazan: TSentr innovatsionnykh tekhnologiy, 608.

18. Rudenko, V. M. (2012) Matematyko-statystychni metody v pedahohichnykh doslidzhenniakh. Rivne: Volynski oberehy, 584.

19. Honcharenko, S. U. (2011). Ukrainskyi pedahohichnyi entsyklopedychnyi slovnyk. Rivne: Volynski oberehy, 552.

20. Karpenchuk, S. H. (2013). Filosofiia osvity (zahalna teoriia pedahohika). Kyiv: Vydavnychyi Dim «Slovo», 688.

21. Cook, D. A., Artino, A. R. (2016). Motivation to learn: an overview of contemporary theories. Medical Education, 50 (10), 997-1014. doi: http://doi.org/10.1111/medu.13074

22. Adams, N., Little, T. D., Ryan, R. M.; Wehmeyer, M., Shogren, K., Little, T., Lopez, S. (Eds.) (2017). Self-Determination Theory. Development of Self-Determination Through the Life-Course. Dordrecht: Springer, 47-54. doi: http://doi.org/10.1007/978-94-024-1042-6_4

23. Ilin, E. P. (2012). Psikhologiya dlya pedagogov. Saint Petersburg: Piter, 640. Ferber, 276

24. Dirksen, D. (2015). Iskusstvo obuchat: kak sdelat lyuboe obuchenie neskuchnym i effektivnym. Moscow: Mann, Ivanov i

25. Ibrahim, M. M., Nat, M. (2019). Blended learning motivation model for instructors in higher education institutions. International Journal of Educational Technology in Higher Education, 16 (1). doi: http://doi.org/10.1186/s41239-019-0145-2

26. Pellas, N. (2014). The influence of computer self-efficacy, metacognitive self-regulation and self-esteem on student engagement in online learning programs: Evidence from the virtual world of Second Life. Computers in Human Behavior, 35, $157-170$. doi: http://doi.org/10.1016/j.chb.2014.02.048

27. Zoabi, K. (2012). Self-Esteem and Motivation for Learning among Minority Students: A Comparison between Students of Pre-Academic and Regular Programs. Creative Education, 3 (8), 1397-1403. doi: http://doi.org/10.4236/ce.2012.38204

Received date 18.05.2021

Accepted date 24.06.2021

Published date 30.07.2021

Tetiana Shrol*, PhD, Department of Information and Communication Technologies and Methods of Teaching Informatics, Rivne State University of the Humanities, S. Bandera str., 12, Rivne, Ukraine, 33028

Nataliia Poliukhovych, PhD, Department of Information and Communication Technologies and Methods of Teaching Informatics, Rivne State University of the Humanities

S. Bandera str., 12, Rivne, Ukraine, 33028

*Corresponding author: Tetiana Shrol,e-mail: shrolt@ukr.net 